\title{
23. Are Women Leaders Different? Margaret Thatcher and Helen Clark
}

\section{Marian Simms}

\section{Introduction}

Untangling the gendered aspects of political leaders' successes provides something of a puzzle. While many studies have demonstrated that gender may be a factor in lack of political success, few studies have examined gender as a factor in success. This is in part for methodological reasons - the number of women leaders is very small - hence quantitative approaches do not work well. Of course, the number of successful women leaders - defined as being re-elected to office - is even smaller. This chapter focuses on two very successful such leaders, the UK's Margaret Thatcher and New Zealand's Helen Clark, asking how and in what ways gender was part of their success. It argues that successful leaders operate on three levels: rhetoric or appearance, process, and policy. Gender is relevant to all three. At its clearest and most obvious, gender is integral to image. 'Pretty boy' Tony Blair, or a Spitting Image (British television satire) sketch featuring cigar smoking Thatcher, are cases in point (Carver 2006: 453). Sinclair (2005) maintains that successful women and indigenous leaders utilise their bodies to differentiate themselves from mainstream leaders to increase trust in the particular organisation.

Traditionally, politics has been a gendered occupation in Britain and other Commonwealth countries. Party leaders were seen as the fathers of the nation. It was no accident that the few early women politicians in were depicted as parliamentary 'mothers'. This was in addition to the first women parliamentarians being political widows and or parliamentary daughters.

Research on barriers to political achievement in Australia ascertained that most senior party officials saw the ideal candidate for parliament as: 'tall, dark and handsome, a good father who attends church' (Sawer and Simms 1993: 66). Women were rarely mentioned as first choice candidates. When prompted, one party official suggested 'the local television weather girl' as a possibility. This and other research indicated that women candidates were not valued in a system where candidate selection is highly centralised and firmly based on tightly organised political parties. Body politics are still significant negatives for many women party leaders. For example media research shows significant negative commentary over matters such as clothes choices and marital status and her childless state, with few positive responses. ${ }^{l}$ Negative stories have been recently 
published over women MPs with small children 'neglecting' their political duties (Stanhope 2007).

Studies have shown a dichotomous model of twentieth century public women as either 'monuments' or 'maidens' (Warner 1985). Margaret Thatcher featured in Warner's pioneering study as a successful leader partly because she had become embodied as a contemporary Boudicca after Britain's successes in the Falklands War (1982). The British tabloids featured Thatcher as a statue (monument) of Britannia draped in the union jack. At that point Thatcher had won the first of three successive election victories (1979) — she would later win in 1983 and 1987 — and had already become demonised by British feminists (see Campbell 1984). The Thatcher government's economic agenda was inimical to the feminist social democratic strategy of working through the state. Thatcher's successful management of the 1982 Falkland's conflict was also at odds with the generally pacifist approach of British feminists and indeed many on the British left. Thatcher was also depicted as an enemy of her sex by conservative admirers as was picked up in the 'iron maiden' soubriquet (Cosgrave 1979).

Contemporary leadership studies utilise qualitative methods to provide useful insights. Leaders' images have also come under careful scrutiny in cognate disciplines such as political marketing and political science. The revival of interest in presidentialism is one case in point. Obsession with image, desire to control the political agenda, playing cabinet favourites, down-grading parliament and so on, are all charges laid against former British Prime minister Tony Blair and his presidential style (see Foley 2004). Blair generally stands accused of monopolising power and being obsessed with projecting his own image. In spite of, or perhaps because of, these attributes he was also politically successful and won successive elections.

In reviewing the Blair legacy, studies are also again taking stock of the Thatcher period, and arguing that Blair is a kind of Thatcher in drag. Thatcher - even more than previously (see for example, Moon 1996) becomes viewed as an innovator, not just in policy terms — as with 'Thatcherism' (see Jenkins 2007) - but in process terms. The key features of her process revolution are working above cabinet, micro managing party research and advertising, creating policy, and creating an American style continuous campaign (Scammell 1996).

The development of 'product Thatcher' was also important, in terms of the government's media strategy. One key difference between Blair and Thatcher relates to party tradition. The Conservative party leader is meant to be the font of policy, whereas the Labour party leader is supposed to express the collective will. Blair has taken the British Labour Party considerably further from its roots than Thatcher took her party - although, arguably, the Conservative party revered cabinet more than Labour. The British Labour party always enjoyed links with other sources of opinion, notably the unions. Thatcher's willingness 
to use friendly peers to oppose her ministers' policies in the House of Lords showed complete cynicism about cabinet conventions (Cosgrave 1979). The downgrading of the cabinet under both Thatcher and Blair has important long-term constitutional implications as well (Foster 2004). In Westminster terms, the leader has taken over the role of cabinet (that 'hyphen and buckle' according to Bagehot 1872: 85), and, equally significantly, taken on the symbolic role of the Monarch, the 'theatrical show of society' (Bagehot 1872: 355).

Turning to New Zealand, successful Labour Prime Minister Helen Clark has also changed important political processes, or the 'way things are done'. Clark rapidly rose to prominence in her 30s during the Labour government of the 1980s, was elected to cabinet in 1987, holding various ministries, was elected as party leader in 1993, and consequently became Prime Minister when the Labour Party was elected to government in November 1999. Her Labour-led government was re-elected in 2002 and $2005 .^{2}$ Like Thatcher, Helen Clark reorganised the operations of the machinery of governing. Clark's informal advisory network or 'kitchen cabinet' has been accused of replacing cabinet as a source of political and policy strategy. ${ }^{3}$ Clark's role as a politico-constitutional innovator has been partly aided by New Zealand's introduction of Multi-Member Proportional (MMP) representation in the mid-1990s. Designed to better represent minority opinion new parties, MMP has led to coalition government with a major impact on the cabinet, which has become a multi-party body. Since 2005 the New Zealand cabinet no longer observes cabinet solidarity. ${ }^{4}$ New policies are sold to the public via extensive government advertising, and the political loyalties of departmental communication chiefs are vetted very closely.

Does image matter? Apart from the growing importance of television during Thatcher's political career, it is arguable that political character is 'created' through repetition. 'Personality' politics is also seen by some (Gaffney 2001; Norton 2003; Foley 2004) as an indicator of presidentialisation. The establishment of 'personality traits' in the minds of voters and the community is created through repetition; and if 'we take Margaret Thatcher, it is probable that throughout the 1980s, the whole United Kingdom population had a notion of her as a person' (Gaffney 2001: 129).

The outlines of the Helen Clark story are well known in New Zealand (James 2005: 5). 'Clark went off to boarding school in Auckland, as brainy rural offspring did ... she lived in a frugal household. Clark's father, George, demanded probity'. Clark's father was featured in the favourable biography by Brian Edwards as commending honesty above all: 'When they (Helen and her sister) were young, if they' $d$ sworn at me, it wouldn't have worried me because I swore at the dogs. But if they'd ever cheated or lied, I'd have been down on them like a ton of hot bricks' (quoted in James 2005: 5). 
Clark, at crucial points - such as in pivotal debates - would self-reference her strict background: 'later she told the Herald she was brought up a Presbyterian went to Sunday school every week ... and at Epsom Girls' Grammar walked "in a crocodile" every Sunday morning to ... Church' (Young 2004: 1).

Such references could easily be provoked by suggestions that her commitment to mainstream values was less than wholehearted. For example, in 2004, the (then) leader of the centre-right National Party, Don Brash, questioned Clark's commitment to Christianity and to the 'institution of marriage' (Young 2004: 1). Clark has also endured media speculation over whether her marriage is genuine or a smokescreen. Previously, Clark had herself stated that she thought legal marriage was 'unnecessary' and she formalised her partnership with sociology academic Peter Davis on the eve of her first running for Parliament in 1981.

Clark's repetition of her story is consistent with the strategies used by contemporary successful national leaders to normalise themselves, and to demonstrate their individuality and personal character through their proven ability to rise above their circumstances. Another recent example of the repeated storyline is Australian Labor Prime Minister Kevin Rudd's regular references to himself as 'Kevin' 'from country Queensland' an 'economic conservative' who grew up in relative poverty, due to his father's untimely death. In Clark's case she has also had to respond to speculation and comments from others questioning her normalcy, and to make a complex judgment as to what is considered normal for a New Zealand woman. While within her support base in the left wing of the Labour Party, bypassing formal marriage or retaining one's given name would be typical in 1981 when she became an MP, this would not have been the case for most women. For example, marriage rates for women in the general New Zealand community were around $85 \%$.

There are multiple such examples of Thatcher's sex being a factor in her career. According to one biographer (Cosgrave 1979: 226) she generated opposition within the Conservative party in the 1970s not because 'she was a woman', but because of 'the kind of woman' she was. Her election as Conservative Party leader was based on the assumption that she would not dominate - due to her gender. Her strong card was that she was not a feminist. Thatcher's subsequent 'toughness' as measured by pollsters, was a surprise to her party supporters in 1979. The political marketing literature features her makeovers designed to soften and provide a common touch - the visits to chocolate factories and supermarkets (Scammell 1996). These 'softenings' tended to happen after she became Prime Minister rather than before.

Unlike Clark, her personal values - repeated regularly to become part of her character - were not modern, but associated with Victorian values (see Skidelsy 1988: iv). For example, Thatcher opposed the 'permissive society', but introduced few policies to stamp it out (Jenkins 2007: 164). She viewed divorce, abortion 
and such like with disfavour but introduced no important legislative changes. Thatcher embodied traditional femininity and was happy to be use make up and makeovers.

Ironically these types of situational makeovers for women tended to be sharply criticised by other women politicians of the era, and studies derived from rich interviews pinpoint the attempted feminisation of women politicos as particularly irritating to them. 'Women reported the way in which the media always include the age of women politicians, what they look like, their domestic and family circumstances, their fashion sense and so on' (Sreberny-Mohammadi and Ross 2000: 108).

Thatcher's significance lay in her capacity to utilise features normally associated with weakness and turn them into strengths. Hence being a woman, a mother and of diminutive, even fragile, appearance were turned into political plusses. One study (Jenkins 2007: 165) even suggested that her successful visit to Latin America was due to her Eva Peron-like appearance. George Schultz presented her with a handbag as a sign of achievement. The irony here is that many studies have indicated that most women politicians have complained bitterly about such depictions and wish to be taken seriously by the media and other politicians.

Thatcher's storyline related to her upbringing in Grantham and her sturdy work ethic as instilled by her father. Yet underlying such folksy stories was a carefully crafted sense of public theatre. Her understanding of political marketing was reflected not so much in her image makeovers but in her sophisticated interpretation of qualitative and quantitative polling. Scammell (1996) points out that Thatcher's riding roughshod over polling figures showing widespread opposition was based on her faith in the Party's qualitative polling that was showing the opposite.

Intertwined with discussions of her sex are discussions of her political skills. She was depicted by some as a 'political innovator' (Moon 1995) and as the first great British political marketer (Scammell 1996). It is now widely accepted that innovation - whether of policy or of process - is the creature of key individuals, often operating in small groups (see Childs and Krook 2006). Thus, critical mass theory and other statistical models do not provide satisfactory explanations of policy innovation and social change.

Two further features, however, are striking about Clark's leadership role. First, she has actively carried her reputation as a supporter of women's issues and indigenous politics with her into the top job. Women were and remain an important support base for Clarke, whereas Thatcher's support among women varied. Research has found that women voters rated women party leaders 'more highly' in New Zealand and Canada than in Australia and Great Britain (Banducci and Karp 2000: 820). This may well be reflected in the kinds of images women politicians' project as well as in policies more generally. 
Clark has probably sought, and certainly generated, positive media treatment over her recent dealings with other prominent women, and complaints by ordinary women regarding sexual assault by police. Ms Clark took a high profile role in the ceremonial burial ceremony for the deceased Maori Queen in 2006. Photographed with high status relatives of the Queen, this image was relayed to national television news programs and was front-page news throughout the country (Stokes 2006). ${ }^{5}$ She established a judicial inquiry into police misbehaviour in 2004 following newspaper allegations of systematic sexual assault on young women by police in the Rotorua district in the North Island of New Zealand, conducted in a culture of cover up. Clark said her 'hair stood on end' at the events outlined by one complainant in a story published in Wellington's Dominion Post newspaper in 2004 (Venter et al. 2004). ${ }^{6}$ Given the lack of credence normally given to sexual assault complainants, the Prime Minister's role was welcomed by feminist organisations and by ordinary women, as reflected in letters to the newspapers and on blogs. One comparable woman leader would be Canada's Kim Campbell, who publicly supported women's issues, but failed to gain re-election.

Clark's public role on women's issues may be related to New Zealand culture where, for example, women's sports enjoy unusually high status - suggesting widespread acceptance of a separate women's culture. Clark is a regular attendee at important netball games. Her own enjoyment of sport, for example squash, skiing and mountain climbing, is well publicised. In traditional Maori society there is also a strong women's culture.

Serious commentators decry the cult of the celebrity that has been fostered by co-dependent media and public relations staff, arguing it has devalued serious political discussion. Yet recent work on leadership (see Collinson 2006, following Burns 1979) reminds us that leaders require followers in whose eyes success is reflected. Deliberately eschewing the so-called leadership traits approach, which specifies a shopping list of attributes for good leadership, 'followership' studies understand leadership in a relational way. Such models are potentially applicable to the public, political arena. They echo existing studies which seek to examine the role of 'gender identity' in responses by voters to leaders.

Second, Clark's long period in office has coincided with a values shift in New Zealand domestic and foreign policies so that, for example, the centre-right opposition party has been forced to adopt a 'no nuclear ships' policy, and has tip toed around the issue of supporting the 'Coalition of the Willing' in Iraq. The Clark government has shifted the role of the state in domestic politics back to the middle after a decade or more of extreme experiments with neo-liberal policies. Remarkably, her government re-nationalised industries, such as the railway track system, oversaw a re-centralisation of the public sector and re-instated a kinder welfare state. 
Leaving aside the current debate over whether Thatcherism created real or imagined policy changes (see Jenkins 2007), Clark's policy shifts may be seen as a left wing equivalent of Thatcher's right wing shift. While the term 'Clarkism' is not in common usage, well-known social democratic thinker, Trotter (2008: 15), argues that Clark's 'brand ... of social liberalism' has created an exodus of social conservatives from New Zealand.

Centralisation is a common theme under both leaders. Thatcher's re-regulation of the UK public sector compares with Clark's strengthening the work of the New Zealand State Services Commission. Both Thatcher and Clark are well known for their high profiles on the international stage. Thatcher's friendships with Ronald Reagan and Mikhail Gorbachev, and the Falklands war, meant she made a strong mark in foreign policy. Again, as with their differing approaches to neo-liberalism, Clark's foreign policy stamp relates to a more moderate, multi-lateralist policy stance.

\section{Conclusion}

Thatcher and Clark have chosen to present themselves as a regal, heroic figures standing for integrity and decency, thus highlighting aspects of women that transcend sexuality. They have turned a media negative - being a female politician — into a positive.

Thatcher's regal status was confirmed during her first term with the Falklands war in 1982. Clark's transition occurred in her third term, with her high profile role at the funeral of the Maori Queen in 2006. Such status transformation has constitutional relevance as the Monarch conventionally has such status under Westminster.

This chapter has also drawn a parallel between Thatcherism and Clarkism. While it has been suggested that Thatcher's real emergence as a conviction politician over the poll tax issue lost her the leadership, it remains to be seen whether Clark will be able to balance pragmatism and conviction through political marketing. Clark's policies on foreign affairs and social welfare have been in a social democratic mode. She has consciously eschewed the triangulation strategies of the likes of Bill Clinton and Tony Blair.

\section{References}

Bagehot, W., 1867, The English Constitution, London: Dent \& son.

Banducci, S. A. and J. A. Karp, 2000, 'Gender, leadership and choice in multiparty systems', Political Research Quarterly, 53:4, pp. 815-48.

Burns, J., 1979, Leadership, New York: Harper/Collins.

Campbell, B., 1984, Wigan Pier Revisited: Poverty and Politics in the Eighties, London: Virago. 
Carver, T., 2006, 'Politics of identity' Government and Opposition, 41:3, pp. 450-68.

Childs, S. and M. L. Krook, 2006, 'Gender and politics: The state of the art', Politics, 26:1, pp. 18-28.

Collinson, D., 2006, 'Rethinking followership: A post-structuralist analysis of follower identities', The Leadership Quarterly, 17:2, pp. 179-89.

Cosgrave, P., 1979, Margaret Thatcher: Prime Minister, London: Hutchinson.

Foley, M., 2004, 'Presidential attribution as an agency of prime ministerial critique in a parliamentary democracy: The case of Tony Blair', British Journal of Politics and International Relations, 6:1, pp. 292-311.

Forster, C., 2004, 'Cabinet government in the twentieth century', The Modern Law Review, 67:5, pp. 753-71.

Gaffney, J., 2001, 'Imagined relationships: Political leadership in contemporary democracies', Parliamentary Affairs, 54:1, pp. 120-33.

James, C., 2005, 'How come the farmer's daughter and the socialist's son swapped roles?', New Zealand Herald, 5 September, p. 3.

Jenkins, S., 2007, 'Thatcher's legacy', Political Studies Review, 5:1, pp. 161-71.

Moon, J., 1995, 'Innovative leadership and policy change: Lessons from Thatcher', Governance, 8:1, pp. 1-15.

Norton, P., 2003, 'The presidentialization of British Politics', Government and Opposition, 38:1, pp. 274-8.

Sawer, M. and M. Simms, 1993, A Woman's Place: Women and Politics in Australia, Sydney: Allen \& Unwin.

Scammell, M., 1996, 'The odd couple: Marketing and Maggie', European Journal of Marketing, 30:10/11, pp. 122-34.

Sinclair, A., 2005, 'Body possibilities in leadership', Leadership, 1:4, pp. 387-406.

Skidelsky, R. (ed.), 1988, Thatcherism, London: Chatto and Windus.

Sreberny-Mohammadi, A. and K. Ross, 2000, 'Women MPs and the media: Representing the body politic', Parliamentary Affairs, 49:1, pp. 103-15.

Stanhope, J., 2007, 'Minister for health attacked for taking maternity Leave', Press release, 14 November.

Stokes, J., 2006, 'Prime Minister pays her respects to monarch', New Zealand Herald, 19 August, p. 1.

Trotter, C., 2008, 'Key will not stem the tide', Otago Daily Times, 2 May, p. 15.

Venter, N., A. Kelly and J. Gordon, 2004, 'My hair stood on end, says PM', Dominion Post, 5 February, p. 1. 
Warner, M., 1985, Monuments and Maidens: Allegory of the Female Form, London: Picador.

Young, A., 2004, 'Insults get personal between Clark and Brash', New Zealand Herald, 16 March, p. 1.

\section{ENDNOTES}

${ }^{1}$ Unpublished Labor Party polling indicates that Ms Gillard is a draw card for women voters. There are indications that stories about her private life have been released by the Party to neutralise rumours that she is gay, because she generally wears pants.

2 Earlier, New Zealand had a centre-right woman Prime Minister Ms Jenny Shipley (1999), and a feminist MP, Dr Marilyn Waring.

3 This group includes Heather Simpson her adviser and Margaret Wilson, the Speaker of the House and former Labour party president.

4 New Zealand First party leader, Winston Peters, is Foreign Minister, and his party has guaranteed supply, but Peters has not pledged loyalty to government policies and is a critic of the free trade agreement with China recently signed by Prime Minister Clark.

5 The Prime Minister was the first woman invited to speak at the 'marae' - Maori community house — during such a ceremony - 'tangihanga'. New Zealand Herald, 19 August 2006.

6 The Report of the Inquiry was released in August 2007. 